\title{
Cover Crops, Nitrogen Cycling, and Soil Properties in Semi-irrigated Vegetable Production Systems
}

\author{
Carol Shennan \\ Department of Vegetable Crops, University of California, Davis, CA 95616
}

The last 5 to 10 years have seen a considerable renewal of interest in the use and management of cover crops among farmers, particularly vegetable producers, in California. Organic growers look to cover crops as an important component of fertility management and efficient nutrient cycling and as a means of improving soil organic matter and structural properties. Moreover, an increasing number of larger-scale vegetable producers are currently experimenting with cover crops, generally in response to concerns for improving soil structure, controlling root pathogens, and/or reducing leaching losses. Historically, the primary purpose of cover crops was to provide supplemental $\mathrm{N}$ for subsequent crops by the use of leguminous species as green manures. But the development of relatively inexpensive sources of synthetic fertilizers caused a severe decline in the use of legumes for supplying $\mathrm{N}$ during the last 50 years (Power, 1987). The incorporation of covercrop biomass into soils also provides additional organic matter inputs into the system, which can, in turn, lead to improved soil organic matter content, physical properties, and water-infiltration characteristics (Bolton et al., 1985; Macrae and Mehuys, 1985; Patrick et al., 1957; Smith et al., 1987; Tisdall and Oades, 1982; Williams, 1966). Increased soil organic matter content is not universally observed in systems that include cover crops in their rotations, e.g., van der Linden et al. (1987) observed little change in soil organic matter content following 20 years of green manure application; but significant changes in soil physical and biological properties can be observed in the absence of large changes in organic $\mathrm{C}$ levels (see later discussion). Following a period of bare fallow with a cover crop also has the potential to reduce leaching losses of mobile nutrients, such as nitrate, and thus reduce groundwater contamination (Muller et al., 1987). This is important when there is sufficient rainfall to cause movement of water down the soil profile, and when the root zone either contains significant amounts of residual nitrate or else temperatures during the fallow period support continued $\mathrm{N}$ mineralization and nitrification. Finally, cover crops may also be grown to provide surface or living mulches as a form of weed suppression (Wallace and Bellinder, 1992), as a means of habitat management to enhance beneficial insect populations (Bugg, 1992), or as a means of reducing soil pathogen severity (van Bruggen et al., 1990).

Until recently, there have been few studies of cover-crop productivity, N-fixation capacity, or the effects of cover-crop incorporation on soil properties conducted in semi-arid or Mediterranean climatic regions. The majority of California's field and vegetable crops are produced in areas characterized by mild winters, with varying amounts of winter rainfall, and hot, dry summers, when frequent irrigations are generally applied for crop production. These conditions favor high rates of biomass and $\mathrm{N}$ accumulation by winter cover crops, as well as rapid decomposition of organic residues added to the soil in the spring. For these reasons it may be inappropriate to extrapolate results obtained in more temperate regions to semi-arid/irrigated areas such as California. This paper will review some of the literature available on cover-crop research in semi-arid regions and highlight findings from studies currently in progress in California. Discussion will be limited primarily to annual cropping systems that include winter cover crops (green manures) that are incorporated into the soil in the spring. There is also grower interest in, and research being conducted on, fastgrowing summer cover crops (Miller et al., 1989), but since the species used, climatic conditions, and production constraints are quite different, they will not be considered here. Similarly, measurements of productivity and $\mathrm{N}$ cycling from cover-cropped orchards cannot be directly extrapolated to annual systems, but pertinent information on soil physical and biological properties will be reviewed. The main focus of the paper will be on winter cover-crop productivity, $\mathrm{N}$ contribution, and the effects of cover-crop incorporation on soil $\mathrm{N}$ cycling, leaching losses, and soil physical and biological properties.

\section{Cover-crop productivity and $\mathrm{N}$ inputs}

Cover-crop biomass, $\mathrm{N}$ accumulation, and, in the case of legumes, the proportion of $\mathrm{N}$ obtained through biological $\mathrm{N}$ fixation vs. soil uptake all depend on species, length of growing season, and climate and soil conditions. Ingeneral there has been little effort to improve the productivity, stress tolerance, or $\mathrm{N}$-fixation capacity of winter cover crops by selection (Smith et al., 1987). Species that have been found to be suitable for use as winter cover crops include: crimson clover (Trifolium incarnatum L.), subterranean clover (T. subterraneum L.), hairy vetch (Vicia villosa Roth.), purple vetch (V. atropurpurea Desf.), lana woollypod vetch $(V$. dasycarpa), bigflower vetch $(V$. grandiflora Scop.), bell beans ( $V$. faba), and Austrian winter peas [Pisum sativum subsp. arvense L. (Poir)]. Common nonlegume species used as cover crops alone or in mixtures with legumes include oats (Avena sativa $\mathrm{L}$.), winter rye (Secale cereale L.), and barley (Hordeum vulgare L.) (Hoyt 
and Hargrove, 1986; Miller et al., 1989; Smith et al., 1987; Stivers and Shennan, 1991). Estimates of above-ground biomass production elsewhere in North America generally ranged between 2000 to 6000 $\mathrm{kg} \cdot \mathrm{ha}^{-1}$ and total $\mathrm{N}$ accumulation 50 to $200 \mathrm{~kg} \cdot \mathrm{ha}^{-1}$ (Table 1). Similar values have been observed for a variety of locations and species in California, but the growth period was generally much shorter than in other regions (Table 1). All of the figures cited in Table 1 were obtained from various kinds of experimental studies, usually from relatively small plots. Interestingly, estimates of productivity and $\mathrm{N}$ accumulation obtained from growers' fields in the Central Valley of California were quite similar to those derived from the experimental plots (Table 2).

If winter legumes are used with the intention of providing a significant component of the $\mathrm{N}$ requirement for a summer cash crop, it is important to assess how much $\mathrm{N}$ the legume provides and whether the time course of release of inorganic $\mathrm{N}$ from the decomposing residue coincides with crop $\mathrm{N}$ demand. In an experiment conducted at Davis, Calif., four legume species [lana woollypod vetch, Austrian winter peas, bell bean, and berseem clover (T. alexandrinum L.)], one mixture of oat plus vetch, and one nonlegume (oat), were compared with six levels of inorganic $\mathrm{N}$ applied as ammonium sulfate to the summer crops in a rotation of corn/corn/tomato/tomato (Stivers et al., 1991; Stivers and Shennan, 1991). Half of the field (four replications) was initially planted to field corn for 2 years followed by 2 years of processing tomato, while the other half had the reverse, i.e., 2 years of tomato followed by 2 years of corn. The cover-crop plots received no supplemental fertilizer. This experiment is now in its 5 th year and data have been collected on cover-crop and summer crop productivity and $\mathrm{N}$ accumulation, as well as changes in soil $\mathrm{N}$ pools throughout the growing seasons. Biomass production of the cover crops has varied over the 5 years (5-year averages given in Table 1), yet lana woollypod vetch has consistently supported yields of field corn and tomato equivalent to those obtained under optimal fertilizer levels (Table 3: data summarized from P.R. Miller, unpublished; C.S. and C.J. Griffin, unpublished; Stivers and Shennan, 1991; Stivers et al., 1991). Some

Table 1. Cover-crop productivity and $\mathrm{N}$ acquisition from experimental studies.

\begin{tabular}{|c|c|c|c|c|}
\hline $\begin{array}{l}\text { Species/ } \\
\text { location } \\
\end{array}$ & $\begin{array}{r}\text { Biomass } \\
\left(\mathrm{kg}^{\left.\cdot h a^{-1}\right)}\right.\end{array}$ & $\begin{array}{l}N \text { content } \\
\left(\mathrm{kg}^{\circ} \mathrm{ha}^{-1}\right)\end{array}$ & $\begin{array}{c}\text { Growth } \\
\text { (months) }\end{array}$ & Source \\
\hline \multicolumn{5}{|l|}{ Kentucky } \\
\hline Hairy vetch & 3350 & 103 & $8-9$ & \multirow{3}{*}{$\begin{array}{l}\text { Blevins et al., } \\
1990(7)^{z}\end{array}$} \\
\hline Bigflower vetch & 2230 & 67 & $8-9$ & \\
\hline Rye & 2010 & 14 & $8-9$ & \\
\hline \multicolumn{5}{|l|}{ Georgia } \\
\hline Hairy vetch & 3430 & 128 & $6-7$ & \multirow{2}{*}{$\begin{array}{c}\text { McVay et al., } \\
1989(3,2)\end{array}$} \\
\hline Crimson clover & 3540 & 108 & $6-7$ & \\
\hline \multicolumn{5}{|l|}{ New York } \\
\hline Hairy vetch & 4390 & 169 & 9 & $\begin{array}{c}\text { Sarrantonio et } \\
\text { al., } 1988(2)\end{array}$ \\
\hline \multicolumn{5}{|l|}{ California } \\
\hline Purple vetch & 3760 & 168 & 5 & \multirow{3}{*}{$\begin{array}{l}\text { Williams \& Ri- } \\
\text { rie, } 1957(1,2) \\
\text { Chapman, } \\
1959(10)\end{array}$} \\
\hline Barley & 4870 & 60 & 5 & \\
\hline Purple vetch & 5400 & 165 & $4-5$ & \\
\hline $\begin{array}{l}\text { Lana woollypod } \\
\text { vetch }\end{array}$ & 6390 & 226 & 5 & \multirow{5}{*}{$\begin{array}{c}\text { Shennan et al., } \\
\text { unpubl. (5) }\end{array}$} \\
\hline Oats/vetch & 7470 & 185 & 5 & \\
\hline Austrian pea & 5350 & 176 & 5 & \\
\hline Fava beans & 3760 & 103 & 5 & \\
\hline Oats & 5370 & 52 & 5 & \\
\hline
\end{tabular}

${ }^{2}$ First number in parentheses refers to number of years from which data were averaged; second number gives number of locations. If no second number is given, data are from a single location. species, notably bell beans, developed disease and pest problems within 3 to 4 years of repeated planting, whereas vetch has not developed any obvious problems to date. Vetch was also the most tolerant to periods of low temperatures among the legumes tested, maintaining higher rates of productivity and $\mathrm{N}$ fixation during the cooler part of the winter than the other legume species (Stivers and Shennan, 1991).

The $\mathrm{N}$ contribution of legumes has often been quantified in units of fertilizer equivalents, usually estimated by comparing crop yields following a legume cover crop with fertilizer response functions obtained following a bare fallow period, a nonlegume cover crop, or fallow plus residue from previous crop (Blevins et al., 1990; Ebelhar et al., 1984; Mckvay et al., 1989; Stickler et al., 1959). Clearly, this method is useful only if a significant fertilizer/yield response is observed and providing the yield following the legume does not fall within a plateau region of the response curve. In the Davis experiment, corn following a bare fallow gave significant yield/N response functions in each year except 1989, when following 2 years of tomato crops. Tomato showed the greatest yield/N response in 1989 when following 2 years of corn (Stivers et al., 1991). Vetch fertilizer equivalent values based on corn yields ranged between 112 to $224 \mathrm{~kg} \mathrm{~N} / \mathrm{ha}$, depending on the year, and for tomato in $1989 \approx 112 \mathrm{~kg} \mathrm{~N} / \mathrm{ha}$ (P.R. Miller, C.S., and C.J. Griffin, unpublished). Thismethod of estimating N contribution has been criticized for greatly overestimating the $\mathrm{N}$ contribution of legumes when compared with estimates obtained from $\mathrm{N}^{15}$ tracer experiments (Hesterman et al., 1987). But the addition of organic residues can affect soil microbial biomass and various indicators of microbial activity (Fraser et al., 1988; Roberson et al., 1991), and hence presumably rates of $\mathrm{N}$ mineralization and immobilization of existing soil $\mathrm{N}$ pools. Therefore, errors associated with the $\mathrm{N}^{15}$ method (see Jenkinson et al., 1985, for discussion of sources of error) may be different for cover-crop and inorganic fertilizer $\mathrm{N}$ sources, which makes comparison of $\mathrm{N}$-use efficiencies complex. Nonetheless, Hesterman et al. (1987) make an important point, namely that crop yield response to a legume can be attributed to $\mathrm{N}$ credits, when in fact other non-N effects may also be significant. In this regard, it is interesting to note that for the last 2 years of the Davis experiment tomato in the vetch treatment outyielded the optimal fertilizer treatments by $\approx 10 \%$ to $15 \%$, which may be related to other effects of vetch incorporation on soil properties.

To estimate whether $\mathrm{N}$ inputs into various cropping systems balance those removed in the harvested material and by other losses from the system, it is necessary to separate the amount of $\mathrm{N}$ in the cover crop derived from biological fixation from that derived from soil reserves. In the first year of the experiment (1986-87), N fixation by the legumes was estimated by the difference method (cf. Williams et

Table 2. Cover-crop productivity and $\mathrm{N}$ acquisition from on-farm studies in California.

\begin{tabular}{|c|c|c|c|c|}
\hline $\begin{array}{l}\text { Species/ } \\
\text { location }\end{array}$ & $\begin{array}{c}\text { Biomass } \\
\left(\mathrm{kg}^{\circ} \mathrm{ha}^{-1}\right)\end{array}$ & $\begin{array}{l}\mathbf{N} \text { content } \\
\left(\mathrm{kg}^{\cdot} \mathrm{ha}^{-1}\right)\end{array}$ & $\begin{array}{c}\text { Growth } \\
\text { (months) }\end{array}$ & Source ${ }^{2}$ \\
\hline \multirow{3}{*}{$\begin{array}{l}\text { Purple vetch } \\
\text { Lana woollypod } \\
\text { vetch }\end{array}$} & 5320 & 178 & 5 & $\begin{array}{l}\text { Klein et al. } \\
\text { unpubl. }(1,3)\end{array}$ \\
\hline & 6390 & 226 & 5 & \\
\hline & 6260 & 215 & $?$ & Drinkwater \& Shen- \\
\hline \multirow[t]{2}{*}{ Oats/vetch } & 6080 & 143 & $?$ & nan, unpubl. $(1,2)$ \\
\hline & 6680 & 121 & $?$ & $(1,2)$ \\
\hline $\begin{array}{l}\text { Faba beans/ } \\
\text { vetch }\end{array}$ & 5070 & 174 & $?$ & (1) \\
\hline $\begin{array}{l}\text { Winter annual } \\
\text { grasses }\end{array}$ & 2870 & 51 & $?$ & (1) \\
\hline Austrian winter & & & & \\
\hline pea & 3190 & 110 & $?$ & (1) \\
\hline
\end{tabular}

2Details as for Table 1 . 
Table 3. Corn and tomato yields between 1987-90. Yields of corn are for grain at $18 \%$ moisture. Values represent the average from 4 years for corn and 3 years for tomato (1988 tomato data not included due to poor stand establishment in all treatments). Numbers in parentheses give the range of yields obtained.

\begin{tabular}{lrr}
\hline Treatment & \multicolumn{1}{c}{$\begin{array}{c}\text { Corn } \\
\left(\mathrm{t}^{-1} \mathrm{ha}^{-1}\right)\end{array}$} & \multicolumn{1}{c}{$\begin{array}{c}\text { Tomato } \\
\left(\mathrm{t}_{\mathrm{ha}}^{-1}\right)\end{array}$} \\
\hline Oats & $6.83(4.9-8.5)$ & $62(55-71)$ \\
Oats/vetch & $10.6(9.0-11.9)$ & $90(78-95)$ \\
Vetch & $12.3(10.9-13.4)$ & $103(95-110)$ \\
Bell beans & $10.2(9.2-11.9)$ & $84(74-94)$ \\
Austrian pea & $11.1(10.2-12.2)$ & $77(73-92)$ \\
$0 \mathrm{~N}^{\mathrm{Z}}$ & $7.7(5.3-10.2)$ & $68(45-82)$ \\
$66 \mathrm{~N}$ & $9.4(8.1-11.2)$ & $85(73-103)$ \\
$112 \mathrm{~N}$ & $11.3(9.7-12.8)$ & $94(83-99)$ \\
$178 \mathrm{~N}$ & $11.7(11.1-12.2)$ & $90(88-93)$ \\
$224(\mathrm{~N})$ & $12.4(11.5-13.0)$ & $89(81-95)$ \\
$290 \mathrm{~N}$ & $12.6(11.8-13.9)$ & $92(89-98)$ \\
\hline
\end{tabular}

Kilograms ammonium sulfate/ha applied to summer crop. Data summarized from Stivers et al. (1991), Stivers and Shennan (1992), P.R. Miller (unpublished), and C.S. and C.J. Griffin (unpublished).

al., 1990), using the oat plots as the reference crop. This method gave average values of $230 \mathrm{~kg} \mathrm{~N} / \mathrm{ha}$ fixed for vetch $(83 \%$ of total $\mathrm{N}$ in above ground biomass), $184 \mathrm{~kg} \mathrm{~N} / \mathrm{ha}(79 \%)$ for Austrian winter pea, and 88 $\mathrm{kg} \mathrm{N} / \mathrm{ha}(68 \%)$ for bell bean (Stivers and Shennan, 1991; P.R. Miller, unpublished). (Berseem clover did not grow well. Early November proved to be too late to achieve good stand establishment with this species, which requires higher temperatures for vigorous seedling growth.) In subsequent years, it was not possible to estimate fixation in this manner due to variation in soil $\mathrm{N}$ availability induced by the treatments. In 1989-90, therefore, subplots of oats were planted into each legume plot in one-half of the field to again estimate fixation. Cover-crop biomass, total $\mathrm{N}$ accumulated and $\mathrm{N}$ fixation were all reduced from 1986-87, which probably reflected the lower winter rainfall and absence of supplemental irrigation in 1989-90. For example, vetch produced $7490 \mathrm{~kg}$ above-ground biomass/ha and accumulated $277 \mathrm{~kg} \mathrm{~N} / \mathrm{ha}$ in 1986-87, vs. $6170 \mathrm{~kg}$ biomass/ha and $208 \mathrm{~kg}$ $\mathrm{N} /$ ha in 1989-90. Of this $\mathrm{N}$, only about one-third was derived by fixation in $1989-90$ vs. $83 \%$ in 1986-87 (E. Lundquist, K.G. Cassman, and C.S., unpublished) This reduction in $\mathrm{N}$ fixation relative to 198687 presumably was related to increased soil $\mathrm{N}$ availability over time (Williams et al., 1990). However, values for $\mathrm{N}$ fixation in 1986-87 also refer to whole-field averages, whereas those for 1989-90 were based on the half of the field planted to tomato for the previous summer. Since residual soil nitrate levels following tomato have been found to be much higher than those following corn, the 1989-90 figures probably underestimate fixation for the field as a whole. By comparison, Larson et al. (1989) at a nearby location obtained estimates of 193 to $247 \mathrm{~kg}$ $\mathrm{N} / \mathrm{ha}$ fixed by white lupin when grown to maturity, which represented $67 \%$ to $78 \%$ of total above-ground plant $\mathrm{N}$.

A primary consideration, particularly in low rainfall years, when assessing relative productivity of cover crops and their suitability for inclusion into a production system, is the amount of water it takes to produce the biomass. Measurements of soil water depletion by vetch from November to the end of March in Winter 1987-88, a year of below-average rainfall, demonstrated that soil moisture was reduced by $<12 \mathrm{~mm}$ in the top $60 \mathrm{~cm}$ of the soil profile, relative to bare-fallow plots (Stivers and Shennan, 1991). This represents a small proportion of the water required to produce a summer tomato crop at this location $(50$ to $60 \mathrm{~cm})$. Planting in early November and turning in the cover crop by the end of March generally avoids periods of high evaporative demand. Nonetheless, further work is needed to better model the relationships between cover-crop productivity, $\mathrm{N}$ fixation, and water use for various planting and incorporation dates, to help growers predict the water costs associated with including a cover crop in their rotations.

\section{Soil nitrogen dynamics}

High soil temperatures and rainfall or irrigation in the spring provide favorable conditions for rapid decomposition of cover-crop residue, particularly legumes with narrow $\mathrm{C}: \mathrm{N}$ ratios in their biomass. Both $\mathrm{N}$ mineralization and nitrification have been found to occur rapidly following lana woollypod vetch incorporation, as shown by a brief peak in soil ammonium levels within 10 to 15 days after incorporation, followed by a rapid increase in soil nitrate (Stivers and Shennan, 1991; C.S. and C.J. Griffin, unpublished). In the presence of corn, soil nitrate pools in the top 0 to $20 \mathrm{~cm}$ were similar in the vetch plots and plots that received $112 \mathrm{~kg}$ ammonium sulfate/ha, reaching a maximum of $30 \mathrm{ppm}$ nitrate $\mathrm{N}$ (dry soil) in first-year corn, and $20 \mathrm{ppm}$ in 2nd-year corn. In comparison, the plots receiving $224 \mathrm{~kg}$ ammonium sulfate/ha reached $50 \mathrm{ppm}$ in first-year corn and $35 \mathrm{ppm}$ in 2nd-year corn, and oat/vetch $\approx 20 \mathrm{ppm}$ in first-year and $15 \mathrm{ppm}$ in second-year corn (C.S. and C.J. Griffin, unpublished). In the presence of a tomato crop, soil nitrate levels were generally higher, reflecting lower $\mathrm{N}$ uptake by the tomato crop than the corn. In this case, nitrate pools were similar in vetch and in the plots with $224 \mathrm{~kg}$ ammonium sulfate/ha, $\approx 40$ to $50 \mathrm{ppm}$ nitrate N (Stivers and Shennan, 1991). Some nitrate was also added in the irrigation water (45 $\mathrm{kg}$ nitrate $\mathrm{N} / \mathrm{ha}$ per year), which would have contributed to soil nitrate pools. Plots receiving no fertilizer or cover-crop residue generally had nitrate levels of 5 to $10 \mathrm{ppm}$ in the presence of corn and 10 to $15 \mathrm{ppm}$ in the presence of tomato. Overall, the time course of $\mathrm{N}$ availability, as indicated by changes in nitrate and ammonium pools during the cropping season, was similar for legume and fertilizer sources (Stivers and Shennan, 1991; C.S. and C.J. Griffin, unpublished).

Measurements of soil inorganic $\mathrm{N}$ pool sizes do not, however, provide any indication of the flux through these pools, and actual patterns of $\mathrm{N}$ availability may be somewhat different (Jackson et al., 1989). Therefore, it is also important to have some estimate of soil $\mathrm{N}$ mineralization capacity throughout the cropping season. Direct measurement of mineralization and immobilization by soil microbes is difficult but has been done using a combination of short-term $\mathrm{N}^{15}$ methods and models of soil N fluxes (Schimel et al., 1989). Simpler techniques have been developed to estimate potential $\mathrm{N}$ mineralization, the most commonly used being either aerobic or anaerobic incubation techniques (Stanford, 1982; Wareing and Bremner, 1964). In greenhouse studies, a combination of initial mineral $\mathrm{N}$ contents and $\mathrm{N}$ mineralization estimated using the above techniques was a good predictor of crop N uptake (Stanford, 1982), but results from field studies have been less conclusive (e.g., Fox and Piekielek, 1984; McCracken et al., 1989). A 7-day anaerobic incubation has been found to correlate closely with soil microbial biomass $\mathrm{N}$ for forest soils (Myrold, 1987). The anaerobic technique has been used to provide an indicator of potentially mineralizable $\mathrm{N}$ throughout the year in the Davis experiment (C.S. and C.J. Griffin, unpublished). Preliminary results indicate that values were consistently $40 \%$ to $50 \%$ higher in cover-cropped than in bare fallow/fertilized plots, and that the highest rates were in the vetch treatment. Similar results were obtained by Stivers and Jackson (1991), who also found elevated rates of potentially mineralizable $\mathrm{N}$ following incorporation of nonlegume cover crops (Phacaelia tanacetifolia cv. Phaci, and rye, Secale cerale 'Merced') in a coastal valley location.

\section{Soil physical and biological properties}

Long-term studies of cover-crop use in orchard systems of California found that 25 years of annual cover crops did not increase the organic C content, total soil $\mathrm{N}$, or water-holding capacity of the soil (Proebsting, 1952). Improvements in water infiltration rates were observed with annual cover-crops treatments intermediate between alfalfa sod and clean-cultivated plots. The conclusion of this and other 
earlier studies cited therein was that "rapid oxidation in the soil" meant that cover crops did not increase soil humus but were in fact entirely lost within a season. Soil $\mathrm{N}$ and organic $\mathrm{C}$ measures were carried out on samples from the surface $30 \mathrm{~cm}$ in Proebsting's study (1952), which could have masked differences that may have existed in the upper soil surface. For example, in the current Davis study, no significant changes in organic $\mathrm{C}$ or total soil $\mathrm{N}$ have been observed over the first 4 years of the experiment in samples taken from 0 to $20 \mathrm{~cm}$ (C.S., C.J. Griffin, and L.J. Stivers, unpublished), whereas Groody (1990) found significantly higher organic $\mathrm{C}$ contents in the surface $5 \mathrm{~cm}$ of vetch $(1.15 \%)$ and oat/vetch $(1.17 \%)$ plots than in bare fallow plots $(0.85 \%$ and $1.05 \%$ for the plots with 0 and $224 \mathrm{~kg}$ ammonium sulfate/ha, respectively). Organic $\mathrm{C}$ or total $\mathrm{N}$ may not, however, be the most useful indicator of changes in soil properties that relate to tilth and other structural characteristics. Properties relating to soil aggregation and biological processes are thought to be important, particularly for long-term maintenance of soil tilth (Karlen et al., 1990). Roberson et al. (1991), working in a California orchard, found significant improvements in macroaggregate slaking resistance and saturated hydraulic conductivity in cover-cropped vs. clean-cultivated treatments in the absence of any changes in organic $\mathrm{C}$ contents. These improvements correlated with enhanced production of "heavy fraction carbohydrates" in the soil, which are thought to be extracellular polysaccharides produced by microorganisms in response to cover-crop $\mathrm{C}$ inputs (Roberson et al., 1991). Similar improvements in macroaggregation stability, saturated hydraulic conductivity, and enhanced polysaccharide production due to vetch incorporation have been observed in the Davis corn/tomato cover-crop study (E.B. Roberson, personal communication). Furthermore, vetch incorporation has been found to reduce the strength of surface crusts induced by sprinkler irrigation, which correlated with improved tomato seedling emergence (Groody, 1990; Stivers et al., 1991). Preliminary water infiltration measurements using a rainfall simulator similarly indicated most rapid infiltration in the oat/vetch plots, while vetch was intermediate between the oat/vetch and the fertilized/bare-fallow plots, which had the slowest infiltration rates (T. Pritchard, personal communication). These observations agree with Williams (1966) and Williams and Doneen (1960), who demonstrated that cover-crop residues effectively improved water infiltration, but that the increase in infiltration was inversely related to the $\mathrm{N}$ content of the residue at incorporation.

\section{Effects on leaching losses}

Vegetable production usually involves high inputs of $\mathrm{N}$, which makes these production areas particularly sensitive to nitrate leaching (Power and Schepers, 1989). cover-cropping during rainy periods on fallow fields could reduce leaching losses and recycle nutrients to subsequent cash crops following residue incorporation. Aldrich (1984) suggested that only 22 to $34 \mathrm{~kg} \mathrm{NO}_{3}-\mathrm{N}$ could be captured in this way and concluded that the practice has limited potential for reducing leaching losses. It is not clear what these figures were based on, but data from other studies suggest that under different conditions cover crops can recycle much larger quantities of N. For example, a catch crop of Italian rye grass (Lolium perenne L.) reduced leaching losses from 110 $\mathrm{kg} \mathrm{N} / \mathrm{ha}$ under bare fallow to $40 \mathrm{~kg} \cdot \mathrm{ha}^{-1}$ in a lysimeter study in France (Martinez and Guiraud, 1990).

In the Davis tomato/corn experiment, a significant amount of residual nitrate was found after tomato harvest in both cover-crop (vetch and oat/vetch) plots and optimal fertilizer plots (112 kg ammonium sulfate/ha). In Fall 1989 the surface 0 -to 20 -cm values were $\approx 20$ $\mathrm{ppm}$ for vetch and oat/vetch and $112 \mathrm{~kg}$ ammonium sulfate/ha, and 40 ppm for the overfertilized $224 \mathrm{~kg}$ ammonium sulfate/ha (Stivers et al., 1991). By the following spring, before cover-crop incorporation, no nitrate could be measured in the oat/vetch plot down to $122 \mathrm{~cm}$ and very little in the vetch plots, suggesting that both cover crops were effective at taking up residual and recently mineralized soil N. In contrast, significant levels of nitrate were measured between 50 and $122 \mathrm{~cm}$ depth in the two bare-fallow/fertilizer treatments (8 and 10-12 ppm in the 112 and $224 \mathrm{~kg} \cdot \mathrm{ha}^{-1}$ treatments, respectively; Stivers et al.,
1991; C.S. and C.J. Griffin, unpublished). As mentioned previously, estimates of soil-derived N vs. N fixed for the cover crops in 1989-90 indicated that vetch acquired $\approx 140 \mathrm{~kg} \mathrm{~N} / \mathrm{ha}$ from the soil. Similarly, reference oat subplots planted into bare-fallow/fertilizer plots accumulated between 85 ( $0 \mathrm{~N}$ treatment) and $140 \mathrm{~kg} \mathrm{~N} / \mathrm{ha}(224 \mathrm{~kg}$ ammonium sulfate/ha) from the soil (E. Lundquist, personal communication). Since the bulk of inorganic soil $\mathrm{N}$ at this location is in the form of nitrate rather than ammonium (Stivers and Shennan, 1991), it is reasonable to assume that much of this $\mathrm{N}$ would have been vulnerable to leaching by winter rains. It is also important to note that the rapid mineralization of legume $\mathrm{N}$ following incoporation in this system implies that it will be as susceptible as fertilizer $\mathrm{N}$ to leaching by overirrigation or rainfall during early seedling growth, although no direct measurements have been taken.

Stivers and Jackson (1991) have demonstrated the potential of nonleguminous winter cover crops to reduce nitrate leaching losses in lettuce production systems. A variety of cover crops were able to accumulate 100 to $175 \mathrm{~kg} \mathrm{~N} / \mathrm{ha}$ from the soil between November and March and significantly reduced soil nitrate pool sizes relative to bare winter fallow. In terms of $\mathrm{N}$ uptake capacity, Phacelia and various grasses and brassicas all looked promising. Phacelia was particularly promising, because its succulent top growth and nonfibrous root system meant that it was easier to beincorporated than thegrasses, and, unlike the brassicas, it did not harbor any potential diseases that could affect neighboring crops (Stivers and Jackson, 1991). However, the ability of rye to reduce corky root (Rhizomoas suberifaciens) of lettuce, a severe root pathogen in this area, enhances its usefulness as a cover crop (van Bruggen et al., 1990).

\section{Limitations and detrimental aspects of cover crops}

When deciding whether to include winter cover crops into a production system, a farmer must consider the potential benefits and costs of the practice. The possible benefits have been discussed above. The constraints and potential negative impacts include extra water consumption, seed costs, additional farming operations involved in establishment and incorporation of the cover crops, and some potential for increased disease/pest problems. Detailed costs were assessed as part of an on-farm study of 20 fresh-market tomato producers (Shennan et al., 1991; L.E. Drinkwater and C.S., unpublished) and from a demonstration study of the use of green manures on various field crop and vegetable producers' farms (J. Klein, C.S., and B.D. Webster, unpublished). In 1989-90, dollar costs associated with production of vetch cover crops (bed preparation, planting, disking and seed costs) ranged from $\$ 16$ to $\$ 30 / \mathrm{ha}$, depending on the farmer (J. Klein personal communication). Only one farmer irrigated the cover crop once after planting; otherwise production depended on winter rainfall and stored soil moisture. A further constraint to the use of cover crops is the problem of reduced flexibility for planting of the summer crop. This problem is particularly severe when dealing with crops requiring early spring plantings, such as processing tomatoes. Research is needed to evaluate reduced tillage options and to optimize techniques and machinery for planting vegetables into recently mowed or incorporated residues.

The effect of cover-crop species on pathogen populations (e.g., fungal pathogens and root nematodes) and insect pest populations is an important consideration in order to prevent more severe development of pest /disease problems over time (Phatak, 1992). While cover crops can have a beneficial influence on pathogens (e.g. van Bruggen et al., 1990; Williams and Ririe, 1957), this is not always the case. Therefore, the ability of particular cover crops to host serious pests and pathogens may limit their utility (Bugg, 1992, for insects; Casswell and Bugg, 1991, for nematodes).

The choice of an appropriate species will depend on the primary reasons for including the cover crop. For example, if the major goal is to reduce nitrate leaching losses, then a species that is able to grow rapidly, develop a deep root system, and deplete soil nitrate pools effectively is desirable. Conversely, if the cover crop is intended to provide $\mathrm{N}$ to a subsequent crop, then the legume species that is able to 
fix the most $\mathrm{N}$ during the available window between cash crops is more appropriate. To provide growers and extension personnel with this kind of information, as well as more precise management considerations for a range of species suitable for use in California, the Univ. of California Sustainable Agriculture Research and Education Program (SAREP, Davis, Calif.) has developed a computerized cover-crop database. This database contains information on soil and climate requirements, disease/pest information, management details, and tolerances to a range of environmental stresses.

In conclusion, cover crops have shown considerable potential as $\mathrm{N}$ sources and as a means of improving soil structural properties and reducing leaching losses in semi-arid irrigated systems. Simple models that can predict biomass production, $\mathrm{N}$ accumulation, and water use for different planting windows would greatly assist growers in deciding the feasibility of including a cover crop in a given rotation. While some cover crops can effectively reduce some soil pathogens, they may increase the severity of others; therefore, careful attention needs to be paid to prevent serious disease build-up. More research is needed in this area of study. Optimal management in terms of covercrop planting, incorporation, and tillage methods before establishment of the subsequent crop are major topics requiring further research, together with improved techniques for modifying fertilizer recommendations for new rotations that include different cover crops.

\section{Literature Cited}

Aldrich, S.R. 1984. Nitrogen management to minimize adverse effects on the soil environment, p. 663-673. In: R.D. Hauck (ed). Nitrogen in crop production. ASA, CSSA, SSSA, Madison, Wis.

Blevins, R.L., J.H. Herbeck, and W.W. Frye. 1990. Legume cover crops as a nitrogen source for no-till corn and grain sorghum. Agron. J. 82:769-772.

Bolton, H., L.F. Elliott, R.I. Papendick, and D.F. Bezdicek. 1985. Soil microbial biomass and selected soil enzyme activities: effect of fertilization and cropping practices. Soil Biol. Biochem. 17:297302.

Bugg, R.L. 1992. Using cover crops to manage arthropods on truck farms. HortScience 27:741-745.

Casswell, E.P. and R.L. Bugg. 1991. Ecological management of plantparasitic nematodes. Components. Technical notes from the Univ. of California Sustainable Agr. Res. and Educ. Program 2(2):6-10.

Chapman, H.D., G.F. Leibig, and D.S. Rayner. 1959. A lysimeter investigation of nitrogen gains and losses under various systems of cover cropping and fertilization, and a discussion of error sources. Hilgardia 19:57-102.

Ebelhar, S.A., W.W. Frye, and R.L. Blevins. 1984. Nitrogen from legume cover crops for no-tillage corn. Agron.J. 76:51-55.

Fox, R.F.and W.P. Piekielek. 1984. Relations among anaerobically mineralized nitrogen, chemical indexes and nitrogen availability to corn. Soil Sci. Soc. Amer. J. 48:1087-1090.

Fraser, D.G., J.W. Doran, W.W. Sahs, and G.W. Lesoing. 1988. Soil microbial populations under conventional and organic management. J. Environ. Qual. 17:585-590.

Groody, K. 1990. Implications for cover crop residue incorporation and mineral fertilizer applications upon crust strength and seedling emergence. MS Thesis. Univ. of California. Davis.

Hesterman, O.B., M.P. Russelle, C.C. Sheaffer, and G.H. Heichel. 1987. Nitrogen utilization from fertilizer and legume residues in legume-corn rotations. Agron. J. 79:726-731.

Hoyt, G.D. and W.L. Hargrove. 1986. Legume cover crops for improving crop and soil management in the southern United States. Hortscience 21(3):397-402.

Jackson, L.E., J.P. Schimel, and M.K. Firestone. 1989. Short-term partitioning of nitrate and ammonium between grassland plants and microbial biomass in an annual grassland. Soil Biol. Biochem. 21:409-415.

Jenkinson, D.S., R.H. Foxand J.H. Rayner, 1985. Interactionsbetween fertilizer nitrogen and soil nitrogen-the so called 'priming effect'. J. Soil Sci. 36:425-444.

Karlen, D.L., D.C. Erbach, T.C. Kaspar, T.S. Colvin, E.C. Berry, and D.R. Timmons. 1990. Soil tilth: a review of past perceptions and future needs. Soil Sci. Soc. Amer. J. 54:153-161.

Larson K.J., K.G. Cassman, and D.A. Phillips. 1989. Yield, dinitrogen fixation and aboveground nitrogen balance of irrigated white lupin in a mediterranean climate. Agron. J. 81:536-543.

Macrae, R.J. and G.R. Mehuys. 1985. The effect of green manuring on the physical properties of temperate area soils. Adv. Soil Sci. 3:7193.

Martinez, J. and G. Guiraud. 1990. A lysimeter study of the effects of a rye catch crop, during a winter wheat/maize rotation, on nitrate leaching and on the following crop. J. Soil Sci. 41:5-16.

McCracken, D.V., S.J. Corak, M.S. Smith, W.W. Frye, and R.L. Blevins. 1989. Residual effects of nitrogen fertilization and winter cover cropping on nitrogen availability. Soil Sci. Soc. Amer. J. 53:1459-1464.

Mckvay, K.A., D.E. Ratcliffe, and W.L. Hargrove. 1989. Winter legume effects on soil properties and nitrogen fertilizer requirements. Soil Sci. Soc. Amer. J. 53:1856-1862.

Miller, P.R., W.L. Graves, W.A. Williams, and B.A. Madson. 1989. Covercrops for California agriculture. Univ. of California Div. Agr. and Natural Resources, Pub. no. 21471, Oakland, Calif.

Muller, J.C., D. Denys, G. Morlet, and A. Mariotti. 1987. Influence of catch crops on mineral nitrogen leaching and its subsequent plant use. In: D.S. Jenkinson and K.A. Smith (eds.). Nitrogen efficiency in agricultural soils, vol. 2. Elsevier, New York.

Myrold. 1987. Relationship between microbial biomass nitrogen and a nitrogen availability index. Soil Sci. Soc. Amer. J. 51:10471049.

Patrick, W.H., Jr., C.B. Haddon, and J.A. Hendrix. 1957. The effect of longtime use of winter cover crops on certain physical properties of commerce loam. Soil Sci. Soc. Amer. Proc. 21:366-368.

Phatak, S.C. 1992. An integrated sustainable vegetable production system. HortScience 27:738-741.

J.F. Power. 1987. Legumes: their potential role in agricultural production. Amer. J. Alternative Agr. 2:69-73.

Power, J.F. and J.S. Schepers. 1989. Nitrate contamination of groundwater in North America. Agr. Ecosystem and Environ. 26:165187.

Proebsting, E.L. 1952. Some effects of long continued covercropping in a California orchard. Amer. Soc. Hort. Sci. 60:87-90.

Roberson E.B., S. Sarig, and M.K. Firestone. 1991. Cover crop management of polysaccharide-mediated aggregation in an orchard soil. Soil Sci. Soc. Amer. J. 55:734-738.

Sarrantonio, M. and T.W. Scott. 1988. Tillage effects on availability of nitrogen to corn following a winter green manure crop. Soil Sci. Soc. Amer. J. 52:1661-1668.

Schimel, J.P., L.E. Jackson, and M.K. Firestone. 1989. Spatial and temporal effects on plant-microbial competition for inorganic nitrogen in a California annual grassland. Soil Biol. Biochem. 21:1059-1068.

Shennan, C., L.E. Drinkwater, A.H.C. van Bruggen, D.K. Letourneau, and F. Workneh.1991. Comparative study of organic and conventional tomato production systems: an approach to on-farm systems studies, p. 109-132. In: J.P. Madden (ed.). Sustainable agriculture in the field. Natl. Academy Press, Washington, D.C.

Smith, M.S., W.W. Frye and J.J. Varco. 1987. Advances in soil science, vol. 7, B.A. Stewart (ed.). Springer-Verlag, New York. p. 96-139.

Stanford, G. 1982. Assessment of soil nitrogen availability. In: F.J. Stevenson (ed.). Nitrogen in agricultural soils. Agronomy Monogr. 22:651-688.

Stickler, F.C., W.D. Shrader, and I.J. Johnson. 1959. Comparative value of legume and fertilizer nitrogen for corn production. Agron. J. 51:157-160.

Stivers, L.J. and LE. Jackson. 1991. Winter cover crops to improve nitrogen cycling in the Salinas valley. Calif. Chapter Amer. Soc. Agron., Proc. 1991 Calif. Plant and Soils Conf,, San Luis Obispo, 31 Jan.-1 Feb. 1991.

Stivers, L.J. and C. Shennan. 1991. Meeting the nitrogen needs of processing tomatoes through winter cover crops. J. Prod. Agr. (In press.)

Stivers, L.J., C. Shennan, L.E. Jackson, K. Groody, C.J. Griffin, and P.R. Miller. 1991. Winter cover cropping in vegetable production systems in California. Proc. 2nd Annu. Intl. Symp. Agroecology and Conservation Issues in Temperate and Tropical Regions, Univ. 
of Padua, Italy, 25-29 Sept. 1990.

Tisdall, J.M. and J.M. Oades. 1982. Organic matter and water stable aggregates in soils. J. Soil Sci. 33:141-163.

van Bruggen, A.H.C., P.R. Brown, C. Shennan, and AS. Greathead. 1990. The effect of cover crops and nitrogen onlettuce corky root. Plant Dis. 74:584-589.

van der Linden, A.M.A., J.A. van Veen, and M.J. Frisel. 1987. Modelling soil organic matter levels after long-term applications of crop residues, farmyard manures and green manures. Plant \& Soil 101:21-28.

Wallace, R.W. and R.R. Bellinder. 1992. Alternative tillage and herbicide options for successful weed control in vegetables. HortScience 27:745-749.

Wareing, S.A. and J.M. Bremner. 1964. Ammonium production in soil under waterlogged conditions as an index of nitrogen availability in forest soils. Soil Sci. Soc. Amer. J. 44:1314-1320.

Williams, W.A. 1966. Management of non-leguminous gren manures and crop residues to improve the infilitration rate of an irrigated soil. Soil Sci. Soc. Amer. Proc. 30:631-634.

Williams, W.A. and L.D. Doneen. 1960. Field studies with green manures and crop residues on irrigated soils. Soil Sci. Amer. Proc. 24:58-61.

Williams, W.A. and D. Ririe. 1957. Production of sugar beets following winter green manure copping in California: I. Nitrogen nutrition, yield disease, and perst status of sugar beets. Soil Sci. Soc. Amer. Proc. 21:88-94.

Williams, W.A., W.L. Graves, and K.G. Cassman. 1990. Nitrogen fixation by irrigated berseem clover versus soil nitrogen supply. J. Agron. Crop Sci. 164:202-207. 